\title{
A study on evaluation of antidepressant effect of Imipramine adjunct with Ashwagandha and Bramhi
}

\author{
Research article
}

$\begin{array}{r}\text { Tamoghna Maiti }{ }^{*}, \text { Anjan Adhikari }{ }^{2}, \text { Amrita Panda }^{3} \\ \text { 1. Assistant Professor, Dept. of Pharmacology, BankuraSammilani Medical College, Bankura } \\ \text { 2. Assistant Professor \& Assistant Director of Medical education, Dept. of H\&FW, Kolkata } \\ \text { 3. Junior Research Felow, Anthropological Survey of India, Nagpur } \\ \hline\end{array}$

\begin{abstract}
Introduction: Depressive disorders increase the risks of self-harm or even suicide in patients. Indigenous drugs are being tried to treat such patient along with conventional antidepressant drugs.
\end{abstract}

Objective: To investigate the antidepressant action of Ashwagandha and Bramhi and also to confirm its efficacy in the behavioral despair animal model of depression.

Material and methods: Normal saline as control $(5 \mathrm{ml} / \mathrm{kg})$, imipramine as standard $(16,32,64$ $\mathrm{mg} / \mathrm{kg})$ and ashwagandha $(50,100,150 \mathrm{mg} / \mathrm{kg})$, bramhi $(20,40,80 \mathrm{mg} / \mathrm{kg})$ as test drugs were introduced to the albino rats weighing between 200-250gm for 2 weeks, $1 \mathrm{hr}$ before electric shock in Learned helplessness test (LHT) and swimming in Forced swimming test (FST). Effects of individual drugs as well as their combination were evaluated.

Result: Avoidance response, escape failure and immobility period in case of imipramine and ashwagandha showed highly significant $(\mathrm{p}<0.01)$ result on individual use. There was no significant result in case of Bramhi used alone except in escape failure and immobility period (FST), where at higher doses it showed significant $(\mathrm{p}<0.01)$ result . But combination of Bramhi and ashwagandha in low doses with low dose of imipramine gave a highly significant result $(\mathrm{p}<0.01)$ in all the parameters.

Conclusion: Ashwagandha had significant antidepressant action, but bramhi had not when used alone. Combination of these two indigenous drugs with imipramine showed high efficacy in animal model.

Key Words: Ashwagandha, Bramhi, Forced swimming test, Indigenous drug, learned helplessness test.

Key massages: Ashwagandha and bramhi showed high efficacy in depression model when combine with low dose imipramine. So these drugs may be tried in the treatment of depression and further scientific research should be under taken for cost effectiveness and reduce the adverse effect of modern therapy.

\section{Introduction:}

Depression is a heterogeneous

*Corresponding Author:

Tamoghna Maiti,

MD (Pharmacology)

Assistant Professor,

Dept. of Pharmacology

BankuraSammilani Medical College,

Bankura-722102.

E-mail:-dr.tamoghna.maiti@gmail.com

Mob: 9903425385 disorder that affects a person's mood, physical health and behaviour. Incidence of depressive mood disorders is rising in the modern stressful society leading to increased risks of self-harm or suicide as well as increased mortality from related general medical conditions.(1) As many as $10-15 \%$ of individuals with this disorder exhibit suicidal tendency during their life time. These groups of patients respond well to anti depressant drugs and in severe 
cases to ECT (Electro Convulsive Therapy).

Treatments of major mood disorders have improved in recent years with the advent of newer antidepressant drugs like TCAs (Imipramine), SSRIs (Fluoxetine), MAO-Is and atypical antidepressants, which are more selective with insignificant side effects. Generally the antidepressant agents are reserved for severe \& otherwise incapacitating depressive disorders.(2) Though they are effective they are not totally devoid of side effects \& relatively expensive for longterm use. Therefore evaluation of natural products for the management of major mood disorders was justified. Research trials are continuing to introduce numerous herbal formulation approved by food and drug administration for the treatment of several psychological conditions.(3) Ashwagandha (Withania somnifera), bramhi (Bacopa monniera) have memory enhancing and anxiolytic effect along with improvement of cognitive function(4) But data relating to their antidepressant action is yet to be established. Therefore it was justified to investigate the antidepressant action of ashwagandha and bramhi in this present study.

Study aim was to investigate the antidepressant actions of ashwagandha and bramhi in behavioural despair animal model of depression for confirmation of the already reported efficacy.

\section{Material \& Methods}

Learned helplessness test (LHT)(5) and Forced swimming test (FST)(6) models were used for preparation of behavioral despair animal model. Albino rats weighing between 200-250gm were allowed free access to food and water adlibitum and were maintained under standard laboratory conditions with a natural light and dark cycle following CPCSEA (Committee For The Purpose Of Control and Supervision on Experiments on Animals) guidelines. The animals were acclimatized for 5 days before behavioral experiments which were carried out between 09.00 A.M and 1.00 P.M.

\section{Apparatus}

1. Gemini Avoidance System: This apparatus is divided into two equal compartments by a retractable door. Floors of the chambers in the shuttle box consisted of stainless steel rods. This apparatus was for LHT.

2. Polypropylene vessel $(45 \times 40 \times 30 \mathrm{~cm})$ for FST, 3.Stop watch, 4. Pediatric nasogastric tube.

Drugs: Pure powder form of the following drugs were obtained from different sources

1. Imipramine (Torrent pharmaceuticals Ltd.)

2. Ashwagandha and Bramhi (Indian Herbs research and supply co Ltd., Saharanpur, Uttarpradesh).

Study Design: Experimental protocol was approved by Institutional Animal Ethics Committee before starting the study. Design of this study was comparative and parallel groups. Animals were divided into 24 groups (12 groups for LHT \& FST each) containing six rats in each group.

Study Groups with drug administered and doses -

\begin{tabular}{|l|l|l|l|l|l|}
\hline Group & $\begin{array}{l}\text { Drugs \& Doses } \\
(\mathrm{mg} / \mathrm{kg})\end{array}$ & Group & $\begin{array}{l}\text { Drugs \& Doses } \\
(\mathrm{mg} / \mathrm{kg})\end{array}$ & Group & $\begin{array}{l}\text { Drugs \& Doses } \\
(\mathrm{mg} / \mathrm{kg})\end{array}$ \\
\hline Group I & $\begin{array}{l}\text { Normal saline } \\
(5 \mathrm{ml} / \mathrm{kg})\end{array}$ & $\begin{array}{l}\text { Group } \\
\text { V }\end{array}$ & Bramhi (20) & $\begin{array}{l}\text { Group } \\
\text { IX }\end{array}$ & Ashwagandha (100) \\
\hline $\begin{array}{l}\text { Group } \\
\text { II }\end{array}$ & Imipramine (16) & $\begin{array}{l}\text { Group } \\
\text { VI }\end{array}$ & Bramhi (40) & $\begin{array}{l}\text { Group } \\
\text { X }\end{array}$ & Ashwagandha (150) \\
\hline Group & Imipramine (32) & Group & Bramhi (80) & Group & Imipramine \\
\hline
\end{tabular}




\begin{tabular}{|l|l|l|l|l|l|}
\hline III & & VII & & XI & $(16)+$ Bramhi (20) \\
\hline $\begin{array}{l}\text { Group } \\
\text { IV }\end{array}$ & Imipramine (64) & $\begin{array}{l}\text { Group } \\
\text { VIII }\end{array}$ & $\begin{array}{l}\text { Ashwagandha } \\
(50)\end{array}$ & $\begin{array}{l}\text { Group } \\
\text { XII }\end{array}$ & $\begin{array}{l}\text { Imipramine (16) } \\
\text { +Ashwagandha (50) }\end{array}$ \\
\hline
\end{tabular}

Following is the schedule for each group $(n=6)$ receiving drug orally through pediatric nasogastric tube with mentioned dose in parenthesis for each test (LHT \& FST).

Normal saline as control, imipramine as standard, Ashwagandha \& bramhi as test drugs were administered orally as per the study protocol. The doses of control, standard and the test drugs were selected after observing the response of pilot doses of each, calculated by considering their recommended dose for clinical use and on the basis of earlier studies available in literature respectively.(7) Freshly prepared suspension of the drugs with vehicle normal saline, was administered orally through a pediatric nasogastric tube followed by $5 \mathrm{ml}$ of distilled water. Each dose of individual and combinations drugs were given for 14 days, $1 \mathrm{hr}$ before the experiment. Earlier studies (8-10) stated that repeated oral administration did not causes signs of intoxication.

\section{Learned Helplessness Test (5):}

In this test, an animal is initially exposed to uncontrollable stress (unavoidable response). When the animal is later placed in a situation in which shock is controllable (escapable), the animal not only fails to acquire the escape responses but also often makes no efforts to escape the shock at all. This escape deficit is reversed by chronic antidepressant treatment.(11)(12) Learned helplessness behavioral tests were performed with the Gemini Avoidance System. This apparatus is divided into two equal compartments by a retractable door. Floors of the chambers in the shuttle box consisted of stainless steel rods. Scrambled shocks were delivered through a shock generator.
The drugs were used at three dose levels. Low dose combination of imipramine, bramhi and ashwagandha was administered orally for $2 \mathrm{wks}$, starting on day $1,60 \mathrm{~min}$ before the inescapable shocks, and on day 12 , the rats were individually placed in the chamber and given 90 inescapable shocks $(0.8 \mathrm{~mA})$ of $15 \mathrm{~s}$ duration at $45 \mathrm{sec}$ intervals. Control rats were not given shocks. On day 14, the rats were subjected to the 30-trial escape test. The animals were individually placed in the shuttle box and given a 5-min adaptation period; a tone signal was given during the first $5 \mathrm{sec}$ of each trial (conditioned response). If there was no avoidance response within this period, the tone signal remained on and a $0.8 \mathrm{~mA}$ shock (15sec duration) was delivered through the grid floor. If no escape response was made within this period, both the tone signal and the shock were automatically terminated. The intertrial interval was $5 \mathrm{~s}$. The number of escape failures and avoidance response which refers to a noncrossing-crossing response during the shock delivery was recorded.

\section{Forced swimming Test (6):}

The test was based on the method described by Porsolt. Rats were made to swim individually in a polypropylene vessel $(45 \times 40 \times 30 \mathrm{~cm})$ with a water level of $20 \mathrm{~cm}$ height and maintain at a temperature $22 \pm 1^{\circ} \mathrm{C}$, this ensued that the rats' feet didn't touch the floor of the vessel and that it could not climb out of it. The entire study was divided in to two sessions.

A. Pretest session: Animals (rats) were forced to swim individually for 15 minutes in the polypropylene container for 14 days. 
B. Test session: 24 hours latter i.e. on $15^{\text {th }}$ day each animal was again forced to swim for a period of 6 minutes in a test session. Each animal made vigorous attempt to get out of the polypropylene container during the first couple of minutes and there after surrendered to experimental conditions and became immobile with occasional escape attempts (characterized by complete cessation of swimming with the head lifting just above the water level as noted). This immobility period, after frenzied attempts to escape is postulated to represent the "Behavioural despair" in an animal experimental model. The total duration of immobility during last 4 minutes of a 6 minutes test was recorded as period of despair.

\section{Statistical Analysis}

Data were statistically analyzed by one way ANOVA followed by Dunnet's ttest. Results were expressed as mean number of each group + standard error of mean $(\mathrm{SEM})[$ mean \pm SEM]. ' $\mathrm{P}$ ' value $<0.05$ was considered significant.

\section{Observation and results}

The results (Table $1 \& 2$ 2) showed significant increase in the number of rats showing avoidance response also reduction in the number of rats showing escape failure and immobility period. Avoidance response and escape failure in case of imipramine and ashwagandha showed highly significant result on individual use. But there was no significant result in case of all doses of bramhi except in case of escape failure and immobility period, bramhi in higher doses showed just significant result. In combination doses there was highly significant increase in the number of avoidance response also reduction in escape failure and in immobility period when compared to low doses of all drugs given alone.

\section{Discussion}

Ashwagandha an indigenous herbal product of Indian origin at the given dose levels produces significant reduction in both the parameters. The potency of Ashwagandha against depression in animal models was demonstrated earlier by Griebel et al(13) who compared the above indigenous herbal products with that of the standard SSRI. Bhattacharya SK \& Goel RK also reported similar reduction in all the parameters which comparable to the present.

Bramhi is famous for its memory enhancing tranquilizing and antioxidant properties.(14) Bramhi in low dose level, no significant reduction in any of the parameter were detected. This is comparable to that of Achiliya GS.(15)

The positive effect of imipramine in the learned helplessness test and Forced swimming test model seems to be due to increased availability of these neurotransmitters norepinephrine (NE) and serotonin (5HT) at the post synaptic site following their reuptake inhibition. But uptake blocked is not directly responsible for antidepressant action. Thus it is attributed to these coronary events that followed the primary drugs on presynaptic $\alpha_{2}, 5 \mathrm{HT}_{1 \mathrm{a}}, 5 \mathrm{HT}_{1 \mathrm{~d}}$ auto receptors and amines turn over in brain. However, the antidepressant action of a drug is due to the respective synaptic sites in the brain region, net effect is enhancement of noradrenergic and serotonergic transmission.(16)

Ashwagandha is an essential popular Indian medical plant with marked antiaging, immunomodulatory, anti anxiety and stress relieving property, acts by normalizing the augmented Lipoxygenese (LPO) activities and enhancing the activities Glutathione peroxidase (GPX).(17) From our study, we have seen that it has marked antidepressant effect and it also causes the enhancement of effect when combined with low dose of imipramine. This result corroborates with Bhattacharya SK.(18) Although it has 
marked memory enhancing activity and antioxidant property but have very little antidepressant effect and our study also shows similar antidepressant effect when used alone. But potentiate the effect of imipramine when combine in low doses.

\section{Conclusion:}

The present study evaluated that Ashwagandha had significant antidepressant action but Bramhi had not when used alone. These two drug showed high efficacy in depression model when combine with low dose imipramine. So these drugs may be tried in the treatment of depression and further scientific research should be under taken towards this dimension.

\section{References}

1. Barker EL, and Blakely RD. Norepinephrine and serotonin transporters: Molecular targets of antidepressant drugs. In, Psychopharmacology: The fourth generation of progress. Raven Press, New York, 1995, PP. 321-333.

2. Ashton H, 1992. Brain Systems, disorders and psychotropic drugs. Black well science, Oxford (Comprehensive Monograph) .

3. Begum VH, Sadique J. Long-term effect of herbal drug Withania somnifera on adjuvant-induced arthritis in rats. Indian J Exp Biol 1988;26:877882.

4. Bhattacharya SK, Bhattacharya A, Kumar A, Ghosal S. Antioxidant activity of Bacopa monniera in rat frontal cortex, striatum, and hippocampus. Phytother Res 2000;14:174-179.

5. Shirayama Y, Chen AC, Nakagawa S, Russell DS, Duman RS. Brain-derived neurotrophic factor produces antidepressant effects in behavioral models of depression. J Neurosci. 2002;22:3251-3261.
6. Michel Bourin, Elisabeth Mocaër, and Roger Porsolt. Antidepressant-like activity of S 20098 (agomelatine) in the forced swimming test in rodents: involvement of melatonin and serotonin receptors. $J$ Psychiatry Neurosci. 2004 March;29(2): 126133.

7. Bhattacharya SK, Bhattacharya A, Sairam K, Ghosal S. Anxiolyticantidepressant activity of Withania somnifera glycowithanolides: an experimental study. Phytomedicine 2000;7:463- 469.

8. Bhattacharya SK, Ghosal S. Anxiolytic activity of a standardized extract of Bacopa monniera in an experimental study. Phytomedicine 1998;5:77-82.

9. Chowdhuri DK, Parmar D, Kakkar P, et al. Antistress effects of bacosides of Bacopa monnieri: modulation of Hsp70 expression, superoxide dismutase and cytochrome P450 activity in rat brain. Phytother Res 2002;16:639-645.

10. Singh HK, Dhawan BN. Effect of Bacopa monniera Linn. (brahmi) extract on avoidance responses in rat.J Ethnopharmacol. 1982 Mar;5(2):20514.

11. Chen A-H, Shirayama Y, Shin K-H, Neve RL, Duman RS (2001) Expression of the cAMP response element binding protein (CREB) in hippocampus produces antidepressant effect. Biol Psychiatry 49:753-762.

12. Willner P (1984) The validity of animal models of depression. Psychopharmacology 83:1-16.

13. Porsolt RD, Anton G, Blavet N, Jalfre M. Behavioural despair in rats: a new model sensitive to antidepressant treatments. Eur J Pharmacol. 1978 Feb 15;47(4):379-91.

14. Griebel G, Simiand J, Serradeil-Le Gal C, Wagnon J, Pascal M, Scatton B, Maffrand JP, Soubrie P. Anxiolyticand antidepressant-like effects of the 
non-peptide vasopressin $\mathrm{V} 1 \mathrm{~b}$ receptor antagonist, SSR149415, suggest an innovative approach for the treatment of stress-related disorders. Proc Natl Acad Sci U S A. 2002 Apr 30;99(9):6370-5. Epub 2002 Apr 16.

15. Achliya GS, Wadodkar SG, Dorle AK.Evaluation of sedative and anticonvulsant activities of Unmadnashak Ghrita.J Ethnopharmacol. 2004 Sep;94(1):7783.
16. Davis L, Kuttan G. Effect of Withania somnifera on CTL activity. J Exp Clin Cancer Res 2002;21:115-118.

17. Abou-Douh AM. New withanolides and other constituents from the fruit of Withania somnifera. Arch Pharm 2002;335:267-276.

18. Bhattacharya SK, Bhattacharya D, Sairam K, Ghosal S. Effect of Withania somnifera dyskinesia. Phytomedicine 2002;9:167-170. 
Table 1: Effect of Bramhi \& Ashwagandha alone and in combination with imipramine on Avoidance response and Escape failure, using learned helplessness test model.

\begin{tabular}{|c|c|c|c|c|c|}
\hline Group & $\begin{array}{c}\text { Drugs } \\
\text { (mg/kg,P.O) }\end{array}$ & $\begin{array}{c}\text { Number of } \\
\text { Avoidance } \\
\text { response } \\
{[\text { mean } \pm} \\
\text { SEM] }\end{array}$ & $\begin{array}{c}\text { Increase } \\
\text { of } \\
\text { number } \\
\text { of } \\
\text { avoidance } \\
\text { response } \\
(\%)\end{array}$ & $\begin{array}{l}\text { Number of } \\
\text { Escape } \\
\text { failure } \\
{[\text { mean } \pm} \\
\text { SEM] }\end{array}$ & $\begin{array}{l}\text { Decrease } \\
\text { of number } \\
\text { of escape } \\
\text { failure }(\%)\end{array}$ \\
\hline I & $\begin{array}{l}\text { Normal saline (5 } \\
\mathrm{ml} / \mathrm{kg})\end{array}$ & $13.33 \pm 0.42$ & 0 & $7.5 \pm 0.43$ & 0 \\
\hline II & Imipramine (16) & $13.83 \pm 0.60$ & 3.75 & $6.33 \pm 0.49$ & 15.6 \\
\hline III & Imipramine (32) & $17.67 \pm 0.88^{\mathrm{a}}$ & 32.56 & $3.83 \pm 0.40^{\mathrm{a}}$ & 48.93 \\
\hline IV & Imipramine (64) & $20.33 \pm 0.71^{\mathrm{a}}$ & 52.51 & $3.17 \pm 0.31^{\mathrm{a}}$ & 57.73 \\
\hline $\mathbf{V}$ & Bramhi (20) & $13.5 \pm 0.43$ & 1.27 & $6.33 \pm 0.49$ & 15.6 \\
\hline VI & Bramhi (40) & $14 \pm 0.58$ & 5.03 & $6 \pm 0.58$ & 20 \\
\hline VII & Bramhi (80) & $14.67 \pm 0.49$ & 10.05 & $5.83 \pm 0.31^{b}$ & 22.27 \\
\hline VIII & Ashwagandha (50) & $16.33 \pm 0.42^{\mathrm{a}}$ & 22.51 & $5.33 \pm 0.33^{\mathrm{a}}$ & 28.93 \\
\hline IX & $\begin{array}{c}\text { Ashwagandha } \\
\text { (100) }\end{array}$ & $16.83 \pm 0.40^{\mathrm{a}}$ & 26.26 & $4.33 \pm 0.42^{\mathrm{a}}$ & 42.27 \\
\hline $\mathbf{X}$ & $\begin{array}{c}\text { Ashwagandha } \\
\text { (150) }\end{array}$ & $19.17 \pm 0.48^{\mathrm{a}}$ & 43.81 & $3.66 \pm 0.33^{\mathrm{a}}$ & 51.2 \\
\hline XI & $\begin{array}{c}\text { Imipramine (16) + } \\
\text { Bramhi (20) }\end{array}$ & $16.33 \pm 0.88^{\mathrm{a}}$ & 22.51 & $4.33 \pm 0.33^{\mathrm{a}}$ & 42.27 \\
\hline XII & $\begin{array}{l}\text { Imipramine (16)+ } \\
\text { Ashwagandha (50) }\end{array}$ & $21 \pm 0.47^{\mathrm{a}}$ & 57.54 & $3 \pm 0.36^{\mathrm{a}}$ & 60 \\
\hline $\begin{array}{l}\text { One } \\
\text { Way } \\
\text { ANOVA }\end{array}$ & \multicolumn{5}{|c|}{$\begin{array}{l}\text { Results are given as no of avoidance response mean } \pm \text { SEM in learned } \\
\text { helplessness test . a-p }<0.001 \text {,b-p }<0.01 \text { Vs simple control (NS) with shock. } N=6 \text { in } \\
\text { each group. }\end{array}$} \\
\hline
\end{tabular}


Table 2: $\quad$ Effect of Bramhi \& Ashwagandha alone and in combination with imipramine on Immobility, using forced swimming test.

\begin{tabular}{|c|c|c|c|}
\hline Group & Treatment (mg/kg, P.O) & $\begin{array}{c}\text { Duration of } \\
\text { immobility mean } \\
(\mathbf{s e c}) \pm \text { SEM }\end{array}$ & $\begin{array}{c}\text { \% Reduction of } \\
\text { duration of } \\
\text { immobility }\end{array}$ \\
\hline I & Normal saline (5 ml/kg) & $185.33 \pm 0.08$ & 0 \\
\hline II & Imipramine (16) & $180.17 \pm 0.91$ & 2.78 \\
\hline III & Imipramine (32) & $132 \pm 1.03^{\mathrm{a}}$ & 28.78 \\
\hline IV & Imipramine (64) & $90 \pm 1.03^{\mathrm{a}}$ & 51.33 \\
\hline V & Bramhi(20) & $184.83 \pm 0.60$ & 0.27 \\
\hline VI & Bramhi(40) & $180 \pm 0.37$ & 2.88 \\
\hline VII & Bramhi(80) & $179 \pm 0.58^{\mathrm{b}}$ & 3.44 \\
\hline VIII & Ashwagandha(50) & $127.83 \pm 1.66^{\mathrm{a}}$ & 31.02 \\
\hline IX & Ashwagandha (100) & $70.17 \pm 2.59^{\mathrm{a}}$ & 62.13 \\
\hline X & Ashwagandha (150) & $120.33 \pm 0.49^{\mathrm{a}}$ & 35.07 \\
\hline XI & Imipramine (16)+ Bramhi (20) & $67.83 \pm 2.64^{\mathrm{a}}$ & 63.4 \\
\hline XII & Imipramine (16)+ Ashwagandha & & \\
\hline One way & Results are given as mean duration of immobility $\pm \mathrm{SEM}^{\mathrm{a}}$ & \\
\hline ANOV in last 4 min. of 6 min. \\
\hline
\end{tabular}

